\title{
RELATIONSHIP OF LARVAL FOOD-PLANTS AND VOLTINISM PATTERNS IN TEMPERATE BUTTERFLIES*
}

\author{
By Frank Slansky, Jr.*** \\ Department of Entomology, Cornell University \\ Ithaca, New York I4850
}

An interesting aspect of phenology is the number of broods that a species produces in the growing season. Even among a fairly uniform group like the butterflies within a restricted geographical area, voltinism patterns of the different species may vary considerably. Explanations of possible causes of, and ecological implications of these patterns have apparently seldom been attempted.

It might be expected that voltinism patterns are often genetically determined and are regulated by some environmental clue (cf. Wigglesworth, 1967), bui knowing the proximate reason does not reveal the ultimate causes that brought the voltinism patterns under such control. Obviously, the presence of a food source for the larvae (and, although less well studied, for the adults as well) will have a major influence on these patterns. The exclusive use of the vernal herb Dentaria by larvae of the West Virginia white, Pieris virginiensis, precludes any more than one brood per season. As an adaptation to feeding on this ephemeral food-plant, the larvae upon entering the pupal stage undergo obligate diapause, even though the genetic mechanism for multivoltinism exists in this species (Shapiro, I97I).

A more subtle explanation of voltinism patterns may emerge from examining larval growth rates on different plants (e.g. Dowdeswell \& Willcox, 196r ; Hovanitz \& Chang, 1962; Sharifi \& Zarea, 1970). Nutritional (including water) differences (Soo Hoo \& Fraenkel, 1966; Waldbauer, 1968; Feeny, 1970; J. M. Scriber and P. P. Feeny, ms. in prep.; Slansky, 1974) and differences in secondary chemical content (Gupta \& Thorsteinson, I960; Nayar \& Thorsteinson, 1963; Feeny, 1970) of different plant species and of the same plant species at different stages of growth in large part determine the growth rates of larvae feeding on the plants, and thus perhaps for

*This work was supported by Hatch Grant NYC-139413 and NSF Grant GB-33398.

***Present address: Department of Zoology, University of Iowa, Iowa City, Iowa 52242.

Manuscript received by the editor April 12, 1974. 
some species, voltinism patterns as well. The purpose for this work is to examine the hypothesis that, of the butterflies in particular climatically similar areas, those which have larval food-plants that are apparently nutritionally unsuitable for much of the growing season will exhibit in general fewer broods per season than those butterflies which have larval food-plants that are apparently nutritionally adequate throughout the season.

\section{METHODS}

In order to examine the hypothesis the number of broods produced per year by, and the larval food-plants of, eighty-six species of butterflies were tabulated for three transition zone areas in eastern and mid-western United States (Forbes, I906; Saunders, I932; Ebner, 1970). Additional food-plant records were obtained from Ehrlich and Ehrlich (I96I) and Shapiro (1966). The voltinism patterns of selected species of these butterflies were then related to changes in the nutritional suitability of their larval food-plants.

\section{Results AND Discussion}

That differences in larval growth rates are reflected in the voltinism patterns of butterflies is seen in the following example. Under similar temperature and humidity conditions the duration of the larval stage of the imported cabbageworm, Pieris rapae, is about is to 20 days on some of its food-plants (Slansky, 1974), while that of the Eastern tiger swallowtail, Papilio glaucus, is about 35 to 45 days on some of its food-plants (J. M. Scriber, unpublished data). As a consequence, $P$. rapae generally exhibits one brood more than $P$. glaucus in the areas where they occur together (Table I).*

Further support for the hypothesis is found when the voltinism patterns of selected butterfly species are examined in relation to seasonal changes in the nutritional suitability of larval food-plants. For example, species whose larvae feed on oaks (Quercus), such as the hairstreaks Satyrium edwardsii, S. liparops, and S. calanus, and the skippers Erynnis brizo, E. horatius, and E. juvenalis, usually have

*Although $P$. glaucus is generally considered to have two broods in the areas surveyed in this study, it may be that there is only one 'true' brood. It appears that a high percentage of the pupae from the previous season emerge in the early summer, constituting the 'true' first brood, and that the remaining pupae emerge later in the summer, constituting an 'apparent' second brood (i.e., not the progeny of the first brood of that season) (Scudder, 1889; R. Lederhouse and J. M. Scriber, unpublished data). 
TABLE 1. Number of broods, larval food-plants, and hibernating stages for several butterflies in three transition zone areas. Data from Forbes (1906), New England (A); Saunders (1932), Allegany State Park, N.Y. (B); and Ebner (1970), Wisconsin (C). $\mathrm{E}=$ egg $\mathrm{L}=$ larva $; \mathrm{P}=$ pupa $\mathrm{A}=$ adult.

\begin{tabular}{lcccc}
\hline & \multicolumn{2}{c}{ Number } & & Hiber- \\
of Broods & nating \\
Species & A $\quad$ B C $\quad$ Larval food-plants & C \\
\hline
\end{tabular}

\section{HESPERIIDAE}

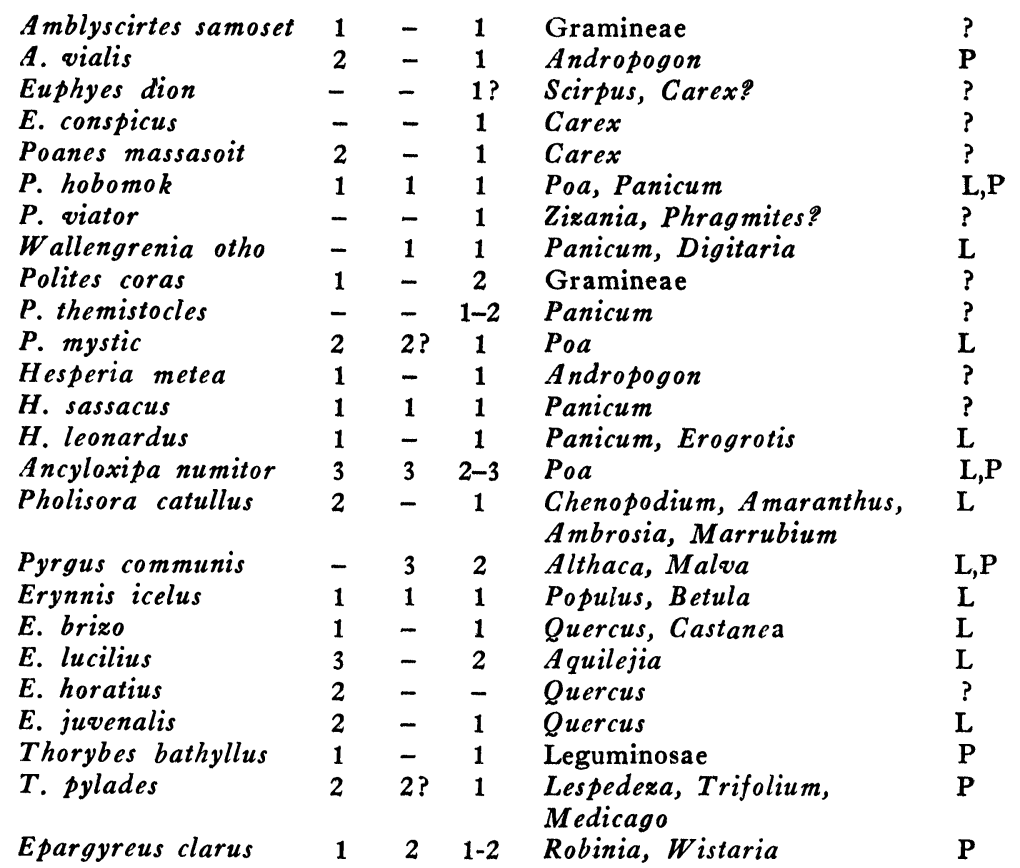

\section{PAPILIONIDAE}

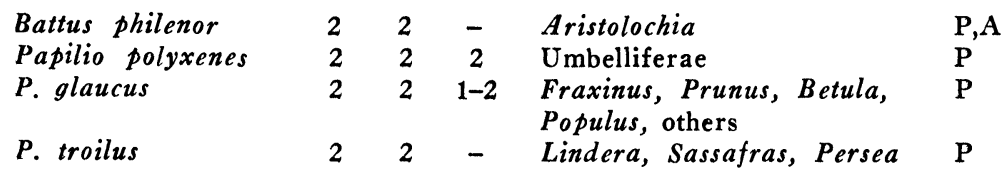


Number

Hiber-

of Broods

nating

Species

A B C Larval food-plants

Stage

\section{PIERIDAE}

$\begin{array}{llll}\text { Pieris protodice } & 3 & - & 3 \\ P . \text { napi } & 3 & - & 3 \\ P . \text { virginiensis } & - & - & 1 \\ \text { P. rapae } & 3 & 3 & 3 \\ \text { Colias eurytheme } & 3 & 3 & 3 \\ \text { C. philodice } & 4 \text { ? } & 3 & 3 \\ \text { C. interior } & 1 & - & 1 \\ \text { Anthocaris midea } & 1 & - & -\end{array}$

Cruciferae

Cruciferae

Dentaria

Cruciferae

Medicago, Trifolium

Trifolium

Vaccinium

Cruciferae, esp. buds, flowers, P seeds

\section{LYCAENIDAE}

Harkenclenus titus Satyrium liparops
S. calanus
S. edwardsii
S. acadica
Callophrys irus
C. henrici
C. augustinus

C. niphon

C. gryneus

Strymon melinus

Lycaena thoe

L. epixanthe

L. phlaeas

Everes comyntas

Celastrina argiolus

NYMPHALIDAE

Asterocampa celtis A. clyton

Limenitis arthemis
Prunus

Quercus, Salix, Rubus, Malus, E

Prunus, Vaccinium, others

Quercus, Carya, Castanea E,L

Ouercus E,L

Salix

E

Babtisia, Crotalaria, Lupinus, $\mathrm{P}$ esp. flowers, fruit

Vaccinium, Prunus, Cercis, $\quad \mathrm{P}$ bores into flowers

Vaccinium, Kalmia, Arbutus, P Arctostaphylus, Ceanothus, esp. flowers and berries

Pinus

$P$

Juniperus

$\mathbf{P}$

$1-2-2$

Polygonum, Phaseolus, Malva, ?

Hypericum, Humulus, others, bores into bud, fruit

Rumex, Polygonum

E

Vaccinium

E

Rumex

Leguminosae, foliage, buds,

L

flowers

Cornus, Rhus, Vaccinium, P

Cimicifuga, Ceanothus, others

$P$
$P$
$P$
$P$
$P$
$L ?$
$?$
$P$




\begin{tabular}{|c|c|c|c|c|c|}
\hline \multirow[b]{2}{*}{ Species } & \multicolumn{3}{|c|}{$\begin{array}{l}\text { Number } \\
\text { of Broods }\end{array}$} & \multirow[b]{2}{*}{ Larval food-plants } & \multirow{2}{*}{$\begin{array}{l}\text { Hiber } \\
\text { natin } \\
\text { Stage }\end{array}$} \\
\hline & A & B & $\mathrm{C}$ & & \\
\hline L. astyanax & $1-2$ & $2 ?$ & 2 & $\begin{array}{l}\text { Prunus, Malus, Pyrus, } \\
\text { Crataegus, Salix, Populus }\end{array}$ & $\mathbf{L}$ \\
\hline L. archippus & 2 & 2 & 2 & Salix, Populus, Prunus, Malus & $\mathrm{L}$ \\
\hline Vanessa atalanta & 2 & 2 & 2 & Urticaceae & $\mathbf{P}, \mathrm{A}$ \\
\hline$V$. virginiensis & 2 & 2 & 2 & $\begin{array}{l}\text { Artemisia, Gnaphalium, } \\
\text { Antennaria, others }\end{array}$ & $\mathbf{P}, \mathrm{A}$ \\
\hline V. cardui & 2 & 2 & 2 & Cirsium, Carduus & \\
\hline Junonia coenia & 2 & - & - & $\begin{array}{l}\text { Plantago, Gerardia, Sedum, } \\
\text { Antirrhinum }\end{array}$ & A? \\
\hline Nymphalis vau-album & $2 ?$ & $2 ?$ & $2 ?$ & Betula, Salix, Populus & A \\
\hline N. milberti & 3 & 2 & 3 & Urtica & A \\
\hline N. antiopa & 2 & 2 & 2 & Ulmus, Celtis, Salix, Populus & A \\
\hline \multicolumn{6}{|l|}{ Polygonia } \\
\hline interrogationis & 2 & 2 & 2 & Ulmaceae, Urticaceae & A \\
\hline P. comma & 2 & 2 & 2 & Ulmaceae, Urticaceae & A \\
\hline P. faunus & 1 & 1 & 1 & Betula, Salix, Alnus, Ribes & A \\
\hline P. progne & 2 & 2 & 2 & Ribes & A \\
\hline Chlosyne nycteis & 2 & 1 & 1 & Helianthus, Actinomeris, Aster & $\mathrm{L}$ \\
\hline C. harrisii & 1 & 1 & 1 & Aster & $\bar{L}$ \\
\hline Phyciodes tharos & 2 & 2 & 2 & Aster & $\mathbf{L}$ \\
\hline P. batesii & $2 ?$ & 1 & 1 & Aster & L? \\
\hline Euphydryas phaeton & 1 & 1 & 1 & Chelone & $\mathbf{L}$ \\
\hline Bolaria selene & 3 & 3 & $2-3$ & Viola & $\mathrm{L}$ \\
\hline B. toddi & 3 & 3 & 2 & Viola & $\mathbf{L}$ \\
\hline Speyeria idalia & 1 & 1 & 1 & Viola & $\mathrm{L}$ \\
\hline S. atlantis & 1 & 1 & 1 & Viola & $\bar{L}$ \\
\hline S. cybele & 1 & 1 & 1 & Viola & $\mathrm{L}$ \\
\hline S. aphrodite & 1 & 1 & 1 & Viola & $\overrightarrow{\mathrm{L}}$ \\
\hline
\end{tabular}

DANAIDAE

$\begin{array}{llllll}\text { Danaus plexippus } & 2 & 2 & 2 & \text { Asclepias } & \text { Migratory }\end{array}$

\section{SATYRIDAE}

Lethe portlandia

L. eurydice

Euptychia cymela

Cercyonis pegala

Oeneis jutta nating

Stage 
one, or at most two, broods, and most hibernate in the larval and/or egg stage (Table I). This may be due to the presence in the oak leaves of tannins that restrict protein utilization and hinder larval development, in many cases limiting consumption of the foliage to spring and early summer when the protein content is highest and the tannin content lowest (Feeny, 1970).

In addition, the leaves of many species of shrubs and trees contain substantially lower percentages of water than the leaves of many annual and perennial herbs (Way, I853; Fagin \& Watkins, 1932; Soo Hoo \& Fraenkel, I966; Slansky, I974; J. M. Scriber, unpublished data). Since the percentage of water in most lepidopterous larvae appears to be about 80 to $90 \%$ (Evans, I939a; 1939b; Wigglesworth, 1967; Slansky, 1974; J. M. Scriber, unpublished data), the growth of larvae feeding on plants with a percentage of water lower than their own tissue may be limited by the availability of water so that they exhibit slower growth rates in comparison to larvae feeding on plants that have a percentage of water equal to or greater than that of the larvae (Southwood, I972; J. M. Scriber \& P. P. Feeny, ms. in prep.). The fact that a number of tree and shrub feeders exhibit but one or two broods (Table I) supports this contention. Along these lines Feeny (1974) has suggested that plant species that are abundant and/or persistent have apparently evolved "quantitative" defenses (low nutrient contents, tough leaves, high contents of unspecific chemicals like tannins) that act as significant ecological barriers to phytophagous insects, in contrast to plant species that are rare and/or ephemeral that have apparently evolved "qualitative" defenses (specific secondary chemicals) that act as only slight ecological barriers to adapted insects although having considerable impact as evolutionary barriers to non-adapted insects.

The majority of grass- and sedge-feeders (all Satyridae and several Hesperiidae), with characteristically sluggish larvae (Scudder, I889), exhibit but one brood (Table I). In view of the low moisture and high fiber content of many grasses (Way, I853; Watson, I95I), it is not surprising that larval development might be slow on such plants. The hibernation of many of these satyrids and hesperiids as early instar larvae (Table I) may be an adaptation for the avoidance of nutritionally poor, mature grass plants and for the maximum utilization of the spring flush of succulent growth when moisture and nitrogen levels are high and fiber content low (Watson, I95I).

Thus, the voltinism patterns of several butterfly species are given an ecological meaning, and the hibernation of many butterfly species as eggs, larvae, and perhaps fertile adults (Scudder, I889), when 
viewed as a means of utilizing tender, nutritious plant tissue in the spring, is seen as an adaptive strategy (c.f. Morse, 197 I Schoener, 197 I). Of course, it is not suggested that the nutritional quality of the larval food-plant is of sole importance in determining voltinism patterns. For example, larvae of both the Tawny crescent, Phyciodes batesii, and the Pearl crescent, $P$. tharos, feed on Aster; the former exhibits one brood and the latter two or three (Table I). Larvae of two Bolaria species and of four Speyeria species all feed on Viola; the former exhibit two to three broods, the latter one brood (Table I). There may be differences in the nutritional quality of different species of plants within these genera, but other factors appear to be causing these differences in voltinism patterns. The Least skipper, Ancyloxipa numitor, larvae of which feed on what might be characterized as 'nutritionally poor' grass plants, exhibits two or three broods while the Eastern black swallowtail, Papilio polyxenes, larvae of which feed on what might be characterized as 'nutritionally adequate' plants in the Umbelliferae, exhibits but two broods (Table I).

Obviously, the interaction of several other factors (e.g. larval size, larval mortality rates, and the presence of adult nectar sources) with the nutritive and secondary chemical contents of the larval food-plants influcnces the voltinism patterns. For example, the slow growth rates of larvae of $P$. glaucus may only be 'permitted' because the combination of the patchy distribution and warning coloration of the larvae may reduce mortality losses from predators and parasitoids (J. M. Scriber, personal comm.). On the other hand, the rapid growth rates of larvae of $P$. rapae may be a 'necessity' because of the nature of its food-plants (i.e., mostly early successional species) and because of the high mortality losses of the larvae to predators, parasitoids, and disease (Richards, I940; Pimentel, I96I ; Dempster, 1969; Parker, 1970). The more rapid growth rates of lepidopterous larvae from 'geographical races' occurring in regions with short growing seasons in comparison to those of larvae from regions with longer growing seasons (Goldschmidt, 1940) provides another example of the ecological importance of differences in larval growth rates.

Such considerations of the interrelationship of life history phenomena and population dynamics (e.g. Cole, I954; Murdock, 1966; Istock, 1967; Gadgil \& Bossert, 1970; Morse, 197 I ; Schoener, 197 I ; Willson, 1971) raise a number of ecologically relevant and as yet insufficiently answered questions, such as: 
I) What are the advantages of monophagous and polyphagous larval feeding habits (c.f. Brues, I920; 1924; Buxton, 1923; Dethier, 1954; Brower, 1958; Schoener \& Janzen, 1968; Levins \& MacArthur, 1969)?

2) Why do some butterflies exhibit a long-lived adult stage (e.g. almost a full year in the Tortoise shell, Nymphalis vau-album) (c.f. Murdoch, 1966; Howe, 1967; Gadgil \& Bossert, 1970)?

3) What selective forces cause the complex voltinism pattern exhibited by a number of butterfly species in which part of a brood becomes dormant while the remainder continues normal development (Scudder, I889; Oliver, 1972)? Perhaps this may allow these species to exploit marginally favorable periods while maintaining a reserve population for the usually favorable season and/or may aid in reducing losses to temporally restricted predators and parasitoids (c.f. Baltensweiler, 1968; Waloff, I968).

4) Why do some butterflies exhibit multivoltinism? Perhaps this is a means of building up large populations to withstand high mortality losses in the summer, especially because of biological causes, and in the winter, especially because of physical causes, such as is seen in several pierid butterflies that start out with low population levels in the spring and become more abundant as the summer progresses (Scudder, I889).

Detailed ecological studies of a taxonomically and geographically well-known group like the butterflies will help to answer such questions and will aid in making meaningful predictions about such important phenomena as the population buildup of a potential or actual pest species.

\section{ACKNOWLeDgements}

The author wishes to thank J. Mark Scriber and William Blau for reading the manuscript and for their helpful suggestions.

\section{Literature Cited}

BALTENSWEILER, W.

1968. The cyclic population dynamics of the grey larch tortrix, Zeiraphera griseana Hubner (=Semasia diniana Guener) (Lepidoptera: Tortricidae), p. 88-97. In T. R. E. Southwood (Ed.). Insect abundance. Symp. Royal Ent. Soc., London \#4. Blackwell Sci. Publ., Oxford.

BROWER, L. P.

1958. Bird predation and foodplant specificity in closely related procryptic insects. American Nat. 92: 183-187. 
Brues, C. T.

1920. The selection of food-plants by insects, with special reference to lepidopterous larvae. American Nat. 54: 313-332.

1924. The specificity of food-plants in the evolution of phytophagous insects. American Nat. 58 : 127-144.

Buxton, P. A.

1923. Animal life in deserts. Edward Arnold and Co., London. 176 p.

Cole, L. C.

1954. The population consequences of life history phenomena. Quart. Rev. Biol. 29: 103-137.

Dempster, J. P.

1969. Some effects of weed control on the numbers of the small cabbage white (Pieris rapae L.) on brussels sprouts. J. Appl. Ecol. 6: 339-345.

Dethier, V. G.

1954. Evolution of feeding preference in phytophagous insects. Evolution $8: 33-54$.

Dowdeswell, W. H., ANd H. N. A. Willcox

1961. Influence of the food-plant on growth rate and pre-imaginal mortality in the green-veined white butterfly Pieris napi (L.) The Ent. 94: 2-8.

EBNER, J. A.

1970. The butterflies of Wisconsin. Milwaukee Public Mus., Popular Sci. Hdbk. \# 12. 205 p.

Ehrlich, P. R., AND A. H. EhrLich

1961. How to know the butterflies. Wm. C. Brown Co., Dubuque, Iowa. $262 \mathrm{p}$.

Evans, A. C.

1939a. The utilization of food by the larvae of the buff-tip, Phalera bucephala (Linn.) (Lepidopt.). Proc. Royal Ent. Soc. London $14(A):$ 25-30.

1939b. The utilization of food by certain lepidopterous larvae. Trans. Royal Ent. Soc. London 89: 13-22.

Fagan, T. W., and H. T. Watkins

1932. The chemical composition of the miscellaneous herbs of pastures. Welsh J. Agr. 8 : 144-150.

FEenY, P.

1970. Seasonal changes in oak leaf tannins and nutrients as a cause of spring feeding by winter moth caterpillars. Ecology 51: 565-581.

1974. Biochemical coevolution between plants and their insect herbivores. In L. E. Gilbert and P. H. Raven (Eds.). Coevolution of animals and plants. Symp. 1st Intern. Congr. Syst. \& Evol. Biol., Boulder, Colo. Univ. Texas Press, Austin. (in press)

Forbes, W. T. M.

1906. Field tables of Lepidoptera. Stanhope Press, Boston. $141 \mathrm{p}$.

GadGIL, M., AND W. H. BOSSERT

1970. Life historical consequences of natural selection. American Nat. 104: 1-24. 
GoLDSCHMIDT, R.

1940. The material basis of evolution. Yale University Press, New Haven. 436 p.

Gupta, P. D., and A. J. Thorsteinson

1960. Food plant relationships of the diamond-back moth (Plutella maculipennis (Curt.)). I. Gustation and olfaction in relation to botanical specificity of the larva. Ent. Exp.. et Appl. 3: 241250.

Hovanitz, W., and V. C. S. Chang

1962. The effect of various food plants on survival and growth rate of Pieris. J. Res. Lep. 1: 21-42.

Howe, R. W.

1967. The influence of age of the parents on some characteristics of the offspring of insects bred in the laboratory. J. Stored Prod. Res. 3 : 371-385.

IsTock, C. A.

1967. The evolution of complex life cycle phenomena: an ecological perspective. Evolution 21: 592-605.

Levins, R., and R. MacArthur

1969. An hypothesis to explain the incidence of monophagy. Ecology 50: $910-911$.

MORSE, D. H.

1971. The insectivorous bird as an adaptive strategy. Ann. Rev. Ecol. and Syst. 2: 177-200.

MURDoch, W. W.

1966. Population stability and life history phenomena. American Nat. 100 : 5-11.

Nayar, J. K., and A. J. Thorsteinson

1963. Further investigations into the chemical basis of insect-host plant relationships in an oligophagous lnsect, Plutella maculipennis (Curtis) (Lepidoptera: Plutellidae). Can. J. Zool. 41: 923-929.

Oliver, C. G.

1972. Genetic and phenotypic differentiation and geographic distance in four species of Lepidoptera. Evolution 26: 221-241.

Parker, F. D.

1970. Seasonal mortality and survival of Pieris rapae (Lepidoptera: Pieridae) in Missouri and the effect of introducing an egg parasite, Trichogramma evanescens. Ann. Ent. Soc. America 63 : 985-994.

Pimentel, D.

1961. An evaluation of insect resistance in broccoli, brussels sprouts, cabbage, collards, and kale. J. Econ. Ent. 54: 156-158.

RichaRDS, O. W.

1940. The biology of the small white butterfly (Pieris rapae), with special reference to the factors controlling its abundance. $J$. Animal Ecol. 9: 243-288.

SAunders, A. A.

1932. Butterflies of the Allegany State Park. Univ. St. N.Y., Albany. $270 \mathrm{p}$. 
SCHOENER, T. W.

1971. Theory of feeding strategies. Ann. Rev. Ecol. and Syst. 2: 369404.

SchoenER, T. W. AND D. H. JANZEN

1968. Notes on environmental determinants of tropical versus temperate insect size patterns. American Nat. 102: 207-224.

SCUDDER, S. H.

1889. The butterflies of the eastern United States and Canada. Publ. by author, Cambridge. Vols. 1 and 2.

ShaPiro, A. M.

1966. Butterflies of the Delaware Valley. Special Publ. American Ent. Soc. Cushing-Malloy, Inc., Ann Arbor, Mich. 64 p.

1971. Occurrence of a latent polymorphism in Pieris virginiensis (Lepidoptera: Pieridae). Ent. News 82: 13-16.

Sharifi, S., AND N. ZaRea

1970. Biology of the citrus butterfly, Papilio demoleus demoleus (Lepidoptera: Papilionidae). Ann. Ent. Soc. America 63 : 1211-1213.

Slansky, F., JR.

1974. Energetic and nutritional interactions between larvae of the imported cabbage butterfly, Pieris rapae L., and cruciferous foodplants. Ph.D. thesis, Cornell Univ., Ithaca, N.Y.

Soo Hoo, C. F., and G. Fraenkel

1966. The consumption, digestion, and utilization of food plants by a polyphagous insect, Prodenia eridania (Cramer). J. Insect Physiol. 12: 711-730.

SoutHwood, T. R. E.

1972. The insect/plant relationship - an evolutionary perspective, p. 3-30. In H. F. van Emden (Ed.). Insect/plant relationships. Symp. \#6, Royal Ent. Soc., London. Blackwell Sci: Publ., Oxford.

WALDBAUER, G. P.

1968. The consumption and utilization of food by insects. Recent Adv. Insect Physiol. 5: 229-288.

WALOFF, N.

1968. A comparison of factors affecting different insect species on the same host plant, p. 76-87. In T. R. E. Southwood (Ed.). Insect abundance. Symp. Royal Ent. Soc. London, \#4. Blackwell Sci. Publ., Oxford.

Watson, S. J.

1951. Grassland and grassland products. Edward Arnold and Co., London. $200 \mathrm{p}$.

WAY, J. T.

1853. On the relative nutritive and fattening properties of different natural and artificial grasses. J. Royal Agr. Soc., England 14: 171-186.

WIGGLESWORTH, V. B.

1967. Principles of insect physiology. Methuen and Co., Ltd., London. 6th ed. $741 \mathrm{p}$.

WiLlson, M. F.

1971. Life history consequences of death rates. Biologist 53:49-56. 

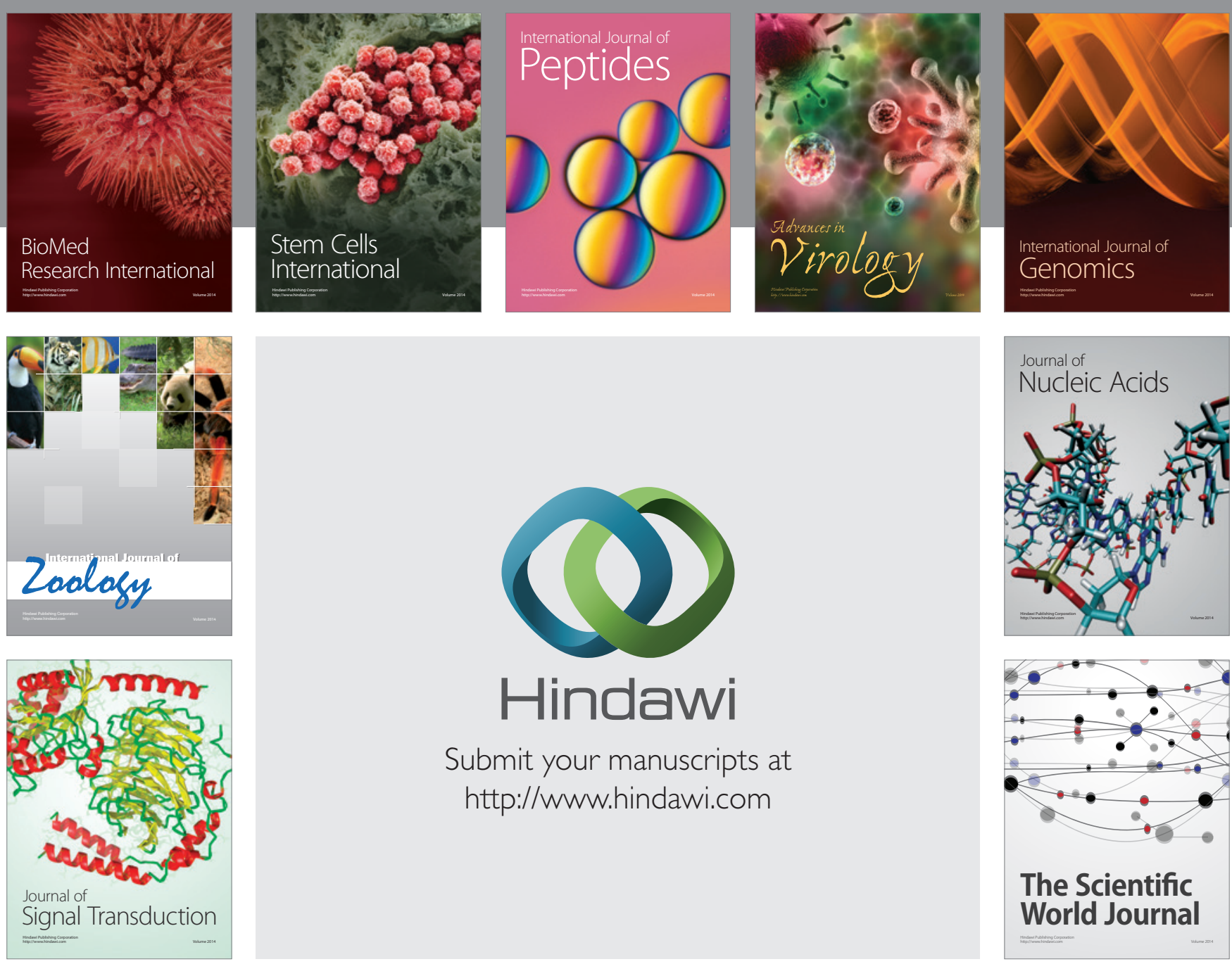

Submit your manuscripts at

http://www.hindawi.com
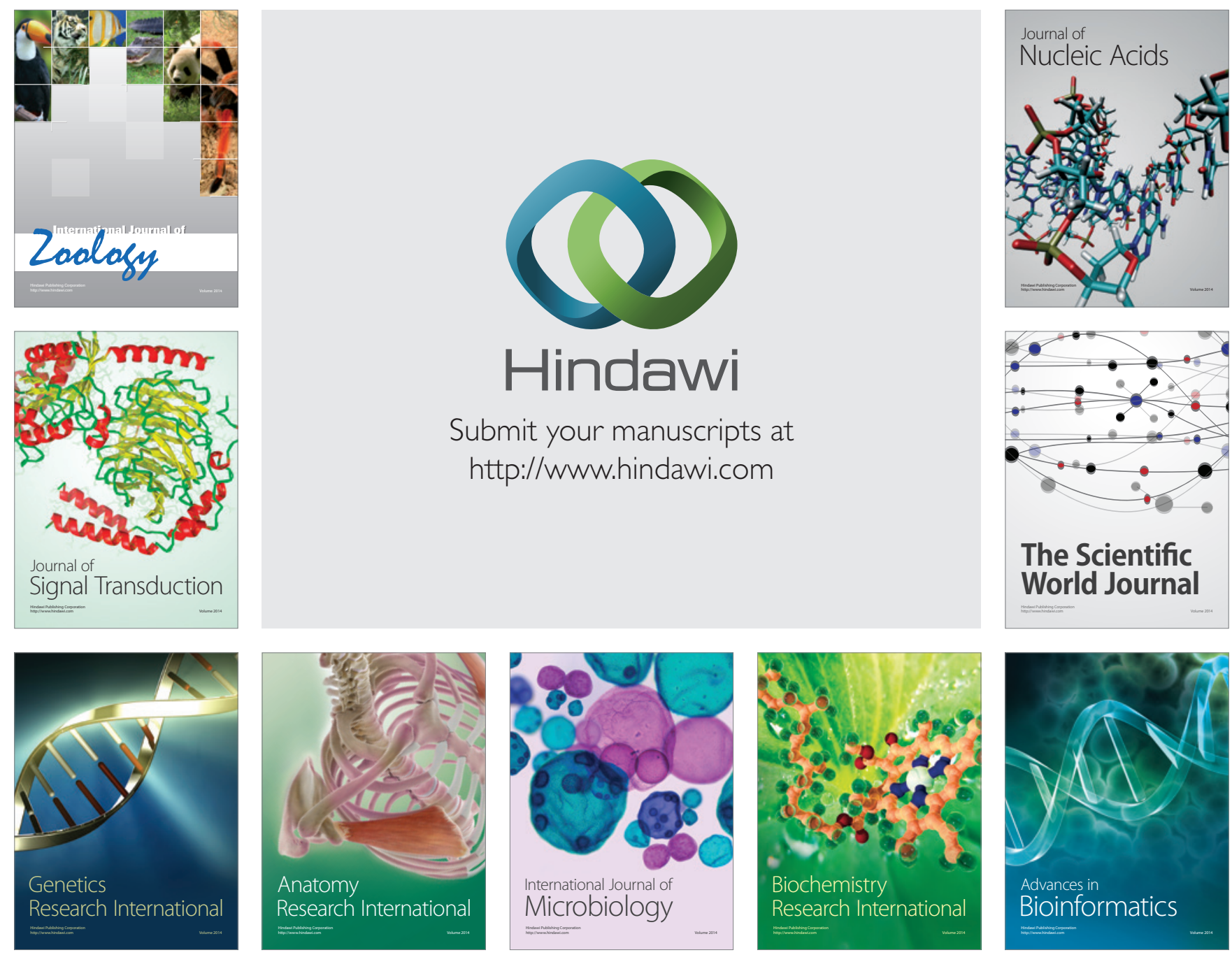

The Scientific World Journal
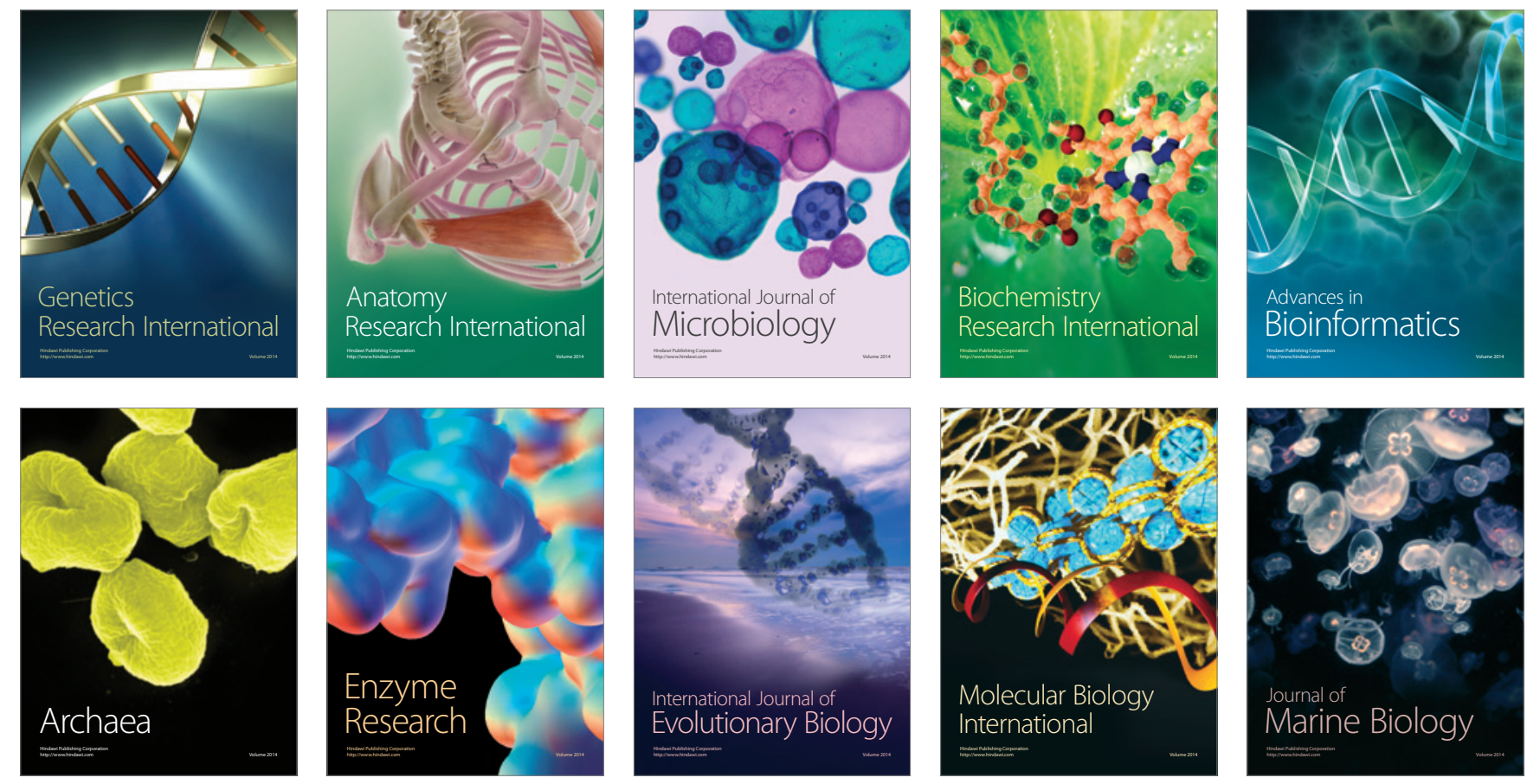